\title{
OPEN Author Correction: The evolutionary consequences for seawater performance and its hormonal control when anadromous Atlantic salmon become landlocked
}

\section{Stephen D. McCormick, Amy M. Regish, William R. Ardren, Björn Thrandur Björnsson 1 \& Nicholas J. Bernier iD}

Correction to: Scientific Reports https://doi.org/10.1038/s41598-018-37608-1, published online 30 January 2019

A supplementary file containing Table S1 was omitted from the original version of this Article. This has been corrected in the HTML and PDF versions of the Article.

\begin{abstract}
(c) (i) Open Access This article is licensed under a Creative Commons Attribution 4.0 International C. License, which permits use, sharing, adaptation, distribution and reproduction in any medium or format, as long as you give appropriate credit to the original author(s) and the source, provide a link to the Creative Commons license, and indicate if changes were made. The images or other third party material in this article are included in the article's Creative Commons license, unless indicated otherwise in a credit line to the material. If material is not included in the article's Creative Commons license and your intended use is not permitted by statutory regulation or exceeds the permitted use, you will need to obtain permission directly from the copyright holder. To view a copy of this license, visit http://creativecommons.org/licenses/by/4.0/.
\end{abstract}

(C) The Author(s) 2019 